\title{
GERAKAN PROTES HAJI SARIP DI KABUPATEN MAJALENGKA 1947
}

\author{
PROTEST MOVEMENT OF HAJI SARIP IN MAJALENGKA 1947
}

\author{
Tia Dwi Nurcahya \\ Universitas Pendidikan Indonesia \\ Jln. Dr. Setiabudhi No. 229 Bandung 40154 Jawa Barat \\ e-mail: dwmachiavellian@gmail.com

\begin{abstract}
Abstrak
Penelitian ini menggambarkan gerakan protes yang dilakukan Haji Sarip terhadap Pemerintah Republik Indonesia tahun 1947 di Kabupaten Majalengka. Untuk merekontruksi permasalahan ini digunakan metode sejarah yang terdiri dari empat langkah penelitian, yaitu heuristik, kritik, interpretasi, dan historiografi. Sedangkan teknik yang digunakan dalam pengumpulan data digunakan studi literatur dan wawancara, yaitu mengkaji sumber-sumber literatur yang berkaitan dengan permasalahan yang sedang dikaji dan mewawancarai saksi sejarah atau pelaku sejarah sebagai narasumbernya. Tujuan penelitian ini adalah mengungkap gerakan protes yang dilakukan Haji Sarip di Kabupaten Majalengka tahun 1947. Berdasarkan hasil penelitian didapat beberapa simpulan: pertama, Haji Sarip melakukan gerakan protes terhadap Pemerintah RI dan desa karena kebijakan yang diambil pemerintah RI, yaitu kebijakannya India Rice (penjualan beras ke India dengan harga murah); kedua, Haji Sarip menganggap Pemerintah RI 1947 sudah gagal dan menyiakan-nyiakan hidup masyarakatnya sendiri, sehingga Haji Sarip akan mengubah tatanan pemerintahan dan menggantikannya dengan pemerintahan baru, yang berlandaskan sama rata sama rasa, sama warna, sama bangsa, dan benderanya putih hitam; ketiga, setelah Haji Sarip melakukan perlawanan terhadap pemerintah dengan cara melakukan provokasi terhadap masyarakat Kabupaten Majalengka, masyarakat dan pemerintah tidak tinggal diam, melainkan masyarakat bersikap antipati terhadap Haji Sarip dan Pemerintah RI menindak Haji Sarip dengan tuduhan membangkang pemerintah, meresahkan masyarakat, menghina tentara dan menjalankan penipuan.
\end{abstract}

Kata kunci: Gerakan protes, Haji Sarip, Majalengka.

\section{Abstract}

This study describes the movement of Haji Sarip protest against the Government of the Republic of Indonesia in 1947 at Majalengka. This research used historical method which consists of four steps of research: heuristics, criticism, interpretation, and historiography. The techniques used in data collection trough literature review and interviews, including reviewing the sources of literature relating to the issues being studied and interviewed witnesses or perpetrators of history. The purpose of this study is to reveal the protest movement Haji Sarip in Majalengka 1947. Based on the results obtained some conclusions: first, Haji Sarip protest movement against the Government and the village because of measures taken by the government of Indonesia, the Indian policy of Rice (rice sales to India with cheap price); second, Haji Sarip assume GOI 1947 has failed and wasted waste life of his own people, so that Hajj Sarip will change the system of government and replace it with a new government, which is based equally the same taste, same color, same nation, black and white flag; Third, after Haji Sarip resistance to the government by way of provocation against Majalengka community, society and the government is not standing still, but the people being antipathy towards Haji Sarip and the government crack down on charges Haji Sarip government's defiant, disturbing the public, insulting the army and run fraud.

Keywords: protest movement, Haji Sarip, Majalengka. 


\section{A. PEN DAHULUAN}

Pasca proklamasi kemerdekaan, muncul suasana revolusi yang bergejolak di Indonesia. Tujuannya adalah untuk mempertahankan kedaulatan negara Republik Indonesia dari tangan Sekutu yang hendak bercokol kembali di Indonesia. Dalam rangka mempertahankan kemerdekaan dari tangan Sekutu, berbagai upaya dilakukan oleh rakyat Indonesia dari adu otak sampai adu otot, dari angkat bicara sampai angkat senjata.

Pemerintahan Indonesia yang pada waktu itu baru berdiri dan mulai merintis kebijakan-kebijakan politiknya, sudah dihadapkan lagi pada permasalahan baru dengan kedatangan pasukan Sekutu yang membonceng NICA. Kedatangan Sekutu ke Indonesia diikuti dengan menerapkan kebijkan-kebijkannya yang merugikan rakyat Indonesia. Akibatnya, keadaan sosial, ekonomi, politik bangsa Indonesia tidak stabil. Salah satu kebijakan Sekutu yang merugikan bangsa Indonesia, seperti adanya blokade ekonomi dari Belanda.

Untuk mengatasi blokade ekonomi Belanda, pada 1946, Pemerintah Indonesia mengeluarkan kebijakan ekonomi yang dikenal dengan istilah India Rice. Kebijakan ini dikeluarkan oleh pemerintah Indonesia dengan alasan untuk memenuhi kebutuhan hidup rakyat Indonesia. Indonesia menjual beras ke India dengan harga murah dengan harapan adanya timbal balik (simbiosis mutualisme) yang diinginkan oleh pemerintah Indonesia yaitu India mengakui di dunia internasional tentang perjuangan bangsa Indonesia. Kemudian sebagai bentuk jalinan kerja samanya dengan Indonesia, selain mengakui perjuangan bangsa Indonesia, pemerintah India juga mengirimkan pakaian ke Indonesia sebagai bentuk kerja samanya (Sudiyo, 2002: 113).

Namun, kebijakan yang dikeluarkan pemerintah Indonesia mengenai India Rice mendapatkan protes dari rakyat Indonesia sendiri, adanya kebijakan tersebut pada akhirnya menimbulkan gejolak di kalangan masyarakat terutama di daerah-daerah pelosok Indonesia yang umumnya dikenal dengan sebutan gerakan rakyat atau revolusi sosial. Kendatipun demikian, sebenarnya permalasahan tersebut bukan satu-satunya alasan rakyat untuk melakukan revolusi sosial. Faktor lain yang memicu adanya gerakan protes ini adalah persaingan para elit-elit lokal dalam pemerintahan. Haji Sarip sebagai pemimpin dalam gerakan ini menghendaki adanya perubahan dalam sistem pemerintah Indonesia di mulai dari pemerintahan setempat, yaitu pemerintah desa dan menggantikannya dengan sistem yang baru yang ia hendaki.

Lucas (1989: 141) menyebutkan alasan lainnya yang mendasari terjadi revolusi sosial atau gerakan masyarakat adalah diakibatkan oleh persaingan politik elite-elite lokal setempat, sebagai contoh, perlawanan di daerah Pekalongan dan Brebes sebagai bentuk ketidakpuasan rakyat terhadap pemimpinnya yang tidak dapat mengurusi rakyatnya. Akibatnya, menuntut adanya pergantian sistem pemerintahan dari sistem yang dinilai lama menuju sistem yang baru.

Hal senada diungkapkan Ricklefs (2008: 440), ia menyebutkan gejolak revolusi sosial di daerah-daerah pedesaan bukan untuk mempertentangkan sistem kelas-kelas sosial, karena kelas sosial yang rendah jarang menumbangkan kelas yang dominan. Kebanyakan revolusi sosial diakibatkan oleh persaingan antar elite-elite alternatif lokal, kelompokkelompok kesukuan atau kemasyarakatan dan antargenerasi.

Pada perkembangannya, konflik atau revolusi sosial seperti di daerah Brebes, Pemalang, dan Tegal yang terjadi pada 1945 memberikan efek domino terhadap daerah-daerah lain di Pulau Jawa.

Pada tahun 1947, di Keresidenan Pekalongan, terjadi gerakan serupa untuk memprotes dan menuntut pemerintah setempat untuk mengubah sistem 
pemerintahan lama yang dipandang tidak dapat mensejahterakan rakyatnya. Di Pekalongan muncul kelompok yang disebut Lenggaong. Lenggaong merupakan bagian penting dari tradisi ini dan mempunyai banyak tokoh"bandit" terkenal. Sama seperti halnya priayi, lenggaong-pun berusaha mendapatkan kekuatan spiritual (Lucas, 2004: 191Di daerah Jawa Barat, kejadian semacam ini salah satunya terjadi di Kabupaten Majalengka yaitu Gerakan Protes Haji Sarip tahun 1947. Haji Sarip dalam protesnya mengajak masyarakat untuk melakukan perubahan kehidupan. Awalnya, ajakan Haji Sarip disambut baik oleh masyarakat setempat, sebagaimana dari keterangan saksi hidup atau pelaku sejarah yaitu H. Kusnan (83 Tahun). Beliau mengungkapkan bahwa Haji Sarip datang dari Purwekerto, awalnya masyarakat Desa Burujul Wetan, Kecamatan Jatiwangi, Kabupaten Majalengka menerimanya karena gagasan Haji Sarip membuat organisasi (Barisan Banteng) yang dinilai oleh masyarakat pada saat itu merupakan sebuah alat revolusi untuk melawan Belanda, akan tetapi sebaliknya Haji Sarip membuat organisasi (Barisan Banteng) tujuannya untuk melawan pemerintah Republik Indonesia dan pamong desa.

Berdasarkan pemaparan di atas, terdapat beberapa permasalahan yang akan dibahas. Adapun permasalahan pokoknya adalah "Mengapa Haji Sarip melakukan protes terhadap pemerintah pada tahun 1947?". Untuk memudahkan dan mengarahkan dalam pembahasan, diajukan beberapa pertanyaan sekaligus sebagai rumusan masalah yang akan dibahas dalam penelitian ini antara lain: (1) Apa yang melatarbelakangi Haji Sarip melakukan protes terhadap pemerintah di Kabupaten Majalengka pada tahun 1947 ?

(2) Bagaimana upaya Haji Sarip menghimpun massa dalam melakukan gerakan protes terhadap pemerintah di Kabupaten Majalengka 1947? (3) Bagaimana reaksi masyarakat terhadap gerakan protes Haji Sarip pada tahun 1947 ?

Adapun yang menjadi tujuan dari penelitian adalah untuk mengungkap sekaligus memberikan gambaran tentang bagaimana gerakan sosial ini muncul dalam kondisi yang cenderung kompleks dengan berbagai sebab-musababnya. Penelitian ini juga diharapkan dapat memperkaya khazanah mengenai gerakan atau protes sosial yang terjadi Indonesia pada umumnya, di Jawa Barat, bahkan Kabupaten Majalengka pada khususnya.

Dalam mengkaji penelitian atau permasalahan yang akan dibahas, peneliti menggunakan literatur terdahulu sebagai sumber rujukan dalam penelitian ini. Walaupun pada prinsipnya, sumbersumber yang menjelaskan mengenai peran atau gerakan protes Haji Sarip secara eksplisit sangat sedikit ditemukan. Tapi, peneliti mencoba memanfaatkan sumbersumber yang sudah ada yang di dalamnya menyinggung mengenai sosok Haji Sarip. Buku pertama, berjudul Riwayat Perjuangan K.H Abdul Halim, karya Miftahul Falah. Walaupun secara judul besar buku tersebut membahas tentang riwayat K.H Abdul Halim, tetapi di dalamnya sedikitnya membahas tentang perlawanan Haji Sarip di Desa Brujul Wetan. Gerakan yang dilakukanoleh Haji Sarip itu sangat bertentangan dengan perjuangan K.H Abdul Halim, dan menurut buku tersebut diterangkan bahwa gerakan yang dilakukan oleh Haji Sarip adalah gerakan bersifat millenaristis dan mencoba mengajak masyarakat Burujul Wetan (Majalengka) mendukung upaya menggantikan tatanan pemerintahan sekarang dengan menata kehidupan yang baru.

Literatur lainnya yang dijadikan bahan acuan dalam penelitian ini adalah berbentuk Jurnal, karya Agus Mulyana dengan judul Pergumulan Elite Sunda pada Masa Revolusi: Kasus Berdiri dan Bubarnya Negara Pasundan, 1947-1950, diterbitkan oleh Pendidikan Sejarah FPIPS UPI. Isinya menjelaskan tentang 
revolusi sosial di Jawa Barat dan persaingan antar elite Sunda pada tahun 1947-1950. Antara kaum menak dan kaum biasa, kaum menak biasanya diidentikkan dengan seorang penguasa atau pemimpin yang mampu mengerahkan massa sedangkan kaum biasa adalah kaum yang hanya mengikuti saja kaum menak. Artinya, kaum biasa tidak mempunyai pengaruh di dalam masyarakat itu sendiri.

Selanjutnya, Jurnal yang ditulis oleh Susanto Zuhdi yang berjudul Antara Sewaka dan Soeria Kartalegawa: Dinamika Politik Pemerintahan di Jawa Barat pada Masa Revolusi Indonesia, diterbitkan oleh Pendidikan Sejarah FPIPS UPI. Dalam tulisannya Zuhdi menjelaskan tentang permasalahan revolusi pasca-kemerdekaan Indonesia. Ia menjelaskan, secara sosioligis, zaman revolusi kecenderungan masyarakat menggunakan emosinya berlebihan, dengan nalar yang dipersempit. Sehingga suasana seperti itu menyebabkan individu atau kelompok sosial untuk memilih antara pro atau kontra terhadap pemerintah Indonesia.Sebagaimana yang dilalukan oleh Kartalegawa dan Sewaka di Jawa Barat, bahwa pilihan seseorang begitu banyak ditentukan oleh orientasi pribadi, latar belakang pendidikan, dan pengalaman sosial yang pernah dilalui.

Selain buku dan jurnal penulis juga menggunakan Skripsi yang ditulis oleh Deni Kuniadi yang berjudul Keresidenan Priangan pada Masa Revolusi: Tinjauan Politik dan Militer (dari Proklamasi hingga Hijrah). Fakultas Sastra Universitas Indonesia. Kurniadi menjelaskan tentang pembentukan badanbadan perjuangan setelah kemerdekaan, seperti BKR dan badan-badan kelaskaran lainnya. Selain itu juga dalam tulisannya dijelaskan tentang rekasi masyarakat Priangan terhadap tentara-tentara Belanda dan Sekutu pasca-kemerdekaan Indonesia

\section{B. METODE PEN ELITIA N}

Metode yang digunakan dalam penelitian ini adalah metode sejarah.
Metode sejarah merupakan metode yang sesuai untuk melakukan penelitian ini karena data-data yang dibutuhkan menyangkut dengan kehidupan di masa lampau. Widja (1988: 19) mengungkapkan bahwa sejarah yang terutama berkaitan dengan kejadian masa lampau dari manusia, tetapi tidak semua kejadian itu bisa diungkapkan (recoverable), sehingga studi sejarah sebenarnya bisa dianggap bukan studi masa lampau itu sendiri, tapi studi tentang jejak-jejak masa kini dari peristiwa masa lampau. Sejalan dengan ini, Gottschalk (2008: 39) berpendapat, metode sejarah adalah proses menguji dan menganalisis secara kritis rekaman dan peninggalan masa lampau.

Adapun tahapan-tahapan dalam metode sejarah menurut Ismaun (2005: 48-50) terdiri dari empat tahap. Tahap pertama adalah heuristik atau proses pengumpulan sumber-sumber sejarah yang relevan dengan topik penelitian; kedua adalah proses kiritik atau verifikasi. Pada prinsipnya, tahapan kritik dilakukan untuk memperoleh dan menyaring otentisitas dan kredibilitas sumber-sumber yang telah ditemukan. Pada tahapan ini, peneliti melakukan pengkajian terhadap sumber-sumber yang didapat untuk mendapatkan kebenaran sumber; tahap ketiga adalah interpretasi, yaitu memaknai atau memberikan penafsiran terhadap fakta yang diperoleh dengan cara menghubungkan satu fakta dengan fakta lainnya; tahap terakhir adalah historiografi, yaitu menyusun dalam bentuk tulisan dengan jelas, sistematis, dan gaya bahasa yang sederhana menggunakan tata bahasa yang baik dan benar.

Secara historis, istilah gerakan sosial muncul pada abad ke-19 M. Istilah ini pada awalnya diperuntukkan dalam menjustifikasi kaum pekerja dalam melakukan protes, mengingat pada saat itu gaung pergesekan antara kaum pemodal dan kelas pekerja sedang santer-santernya. Memasuki abad ke-20, istilah gerakan 
sosial atau protes sosial mengalami pelebaran makna. Isilah tersebut tidak lagi terpaku pada definisi asalnya.

Untuk mempertajam analisis dalam penelitian ini dibutuhkan pendekatanpendekatan dari berbagai disiplin ilmu sosial. Sebagaimana yang diungkapkan Kartodirdjo (1992: 2), "Langkah yang sangat penting dalam membuat analisis sejarah ialah menyediakan suatu kerangka pemikiran yang bisa digunakan melalui konsep atau teori yang akan dipakai dalam membuat analisis itu". Kaitannya dengan ini, penulis menggunakan pendekatan ilmu sosial perspektif sosiologi dengan memakai teori konflik.

Teori konflik adalah teori yang memandang bahwa perubahan sosial tidak terjadi melalui proses penyesuaian nilainilai yang membawa perubahan, tetapi terjadi akibat adanya konflik yang menghasilkan kompromi-kompromi yang berbeda dengan kondisi semula. Teori konflik muncul sebagai reaksi dari munculnya teori struktural fungsionalisme. Pemikiran yang paling berpengaruh atau menjadi dasar dari teori konflik ini adalah pemikiran Karl Marx. Pada tahun 1950-an dan 1960-an, teori konflik mulai merebak. Teori konflik menyediakan alternatif terhadap teori struktural fungsional. Pada saat itu Marx mengajukan konsepsi mendasar tentang masyarakat kelas dan perjuangannya (http://etan.org/etanpdf/2006/CAVR/bh/0

4-RezimPendudukan.pdf; diakses, 8 Maret 2014).

Marx tidak mendefinisikan kelas secara panjang lebar. Namun, ia menunjukkan bahwa dalam masyarakat pada abad ke- 19 di Eropa terdiri dari kelas pemilik modal (borjuis) dan kelas pekerja (proletar). Kedua kelas ini berada dalam suatu struktur sosial hirarkis, kaum pemilik modal melakukan eksploitasi terhadap kaum proletar dalam proses produksi. Eksploitasi ini akan terus berjalan selama kesadaran dari kaum pekerja belum terbentuk dan memiliki rasa menyerah diri atau putus asa.
Sebaliknya, ketika rasa rendah diri itu telah hilang maka akan muncul pertentangan atau konflik yang disebut dengan gerakan sosial atau gerakan protes.

Selain teori, penulis juga menggunakan sebuah konsep guna mempertajam daya analisis, yakni konsep revolusi. Konsep revolusi biasanya digunakan untuk menelaah gerakan sosial dalam menuntut adanya perubahan sistem, kebijakan pemerintah. Menurut KBBI "revolusi adalah perubahan ketatanegaraan, pemerintah atau keadaan sosial yang dilakukan dengan kekerasan seperti dengan perlawanan bersenjata" (Depdiknas, 2008: 1172). Revolusi berasal dari bahasa Latin re-volvere, artinya menjungkirbalikkan. Revolusi dapat juga dinamakan sebagai persamaan dari perubahan secara tiba-tiba atau perubahan cepat, karena ketika berbicara revolusi biasanya masyarakat akan terasosiasi terhadap perubahan.

Revolusi merupakan perubahan secara cepat dan tiba-tiba dalam berbagai aspek dari suatu negara. Maksudnya mengubah tata nilai yang telah lama dan digantikan dengan sistem yang lain dan bentuknya berlainan sama sekali dengan yang lama.

Dari segi ideologi revolusi dapat diartikan apa yang sesuai dengan cita-cita sendiri dan apa yang bertentangan dengan itu dianggap dengan kontra-revolusi. Suasana atau iklim revolusi berhubungan dengan perasaan umum bahwa hal-hal yang telah lama harus ditinggalkan secara radikal, artinya sampai ke akar-akarnya dan mengubah kondisi lama dengan pemirikan baru. sesuatu yang baru dan lebih baik dari yang sudah ada. Biasanya, revolusi dilakukan dengan sikap secara keras menolak yang lama dan menggantikan dengan yang baru dengan penghargaan yang meluap-luap (Simatupang dalam Frederick. 2005: 76).

Penggunaan konsep revolusi dalam penelitian mengingat ada kemiripan dengan gerakan protes yang dilakukan 
Haji Sarip ini. Kendati, pada kenyataannya gerakan yang digelorakan oleh Haji Sarip ini relatif tidak menggunakan kekerasan, apalagi sampai melakukan kokang senjata, sebagaimana peristiwa-peristiwa lainnya yang pernah terjadi di Indonesia. Korelasi konsep revolusi dengan penelitian ini dilihat dari tujuan gerakan protes yang menghendaki adanya perubahan dalam sistem pemerintahan dari sistem yang dinilai lama menuju sistem baru yang ia yakini (sosialis-komunis) sebagai sebuah kebenaran.

\section{HA SIL DAN BAHASAN}

\section{Latar Belakang Peristiwa}

Meletusnya Gerakan protes yang dilancarkan Haji Sarip di Kabupaten Majalengka sesungguhnya tidak dapat dilepaskan dari konstelasi politik Indonesia pada saat itu. Keadaan politik Indonesia yang belum stabil di awal kemerdekaan dan diperparah dengan kehadiran Sekutu ke Indonesia sambil menggandeng NICA, semakin memperburuk keadaan sosial, politik, ekonomi, bangsa Indonesia. Di bidang ekonomi, Belanda mengeluarkan kebijakan blokade ekonomi Indonesia, sehingga akses atau pintu kerja sama, perdagangan Indonesia dengan pihak luar terhenti. Sejak itu, Indonesia mengalamai inflasi yang sangat tinggi dan terjadi kekosongan kas negara.

Menanggapi kejadian ini, pada tahun 1946, pemerintah Indonesia di bawah pimpinan PM Sjahrir mengeluarkan kebijakan untuk menerobos blokade ekonomi Belanda. Keputusan pemerintah ini selanjutnya direalisasikan oleh pemerintah dengan mengeluarkan kebijakan India Rice atau diplomasi beras. Pemerintah berdalih, kebijakan tersebut dikeluarkan di samping untuk bertahan dari blokade Belanda, juga untuk meminta dukungan kepada India tentang perjuangan rakyat Indonesia yang mempertahankan kedaulatannya. Penjualan beras dengan harga murah kepada pihak India dinilai sebagai salah satu cara untuk menarik perhatian dunia agar mengakui perjuangan bangsa Indonesia dalam mempertahankan kemerdekaannya (Sudiyo, 2002:113).

Namun, kebijakan yang diambil oleh pemerintah RI pada kenyataannya, justru menimbulkan permasalahan baru di kalangan masyarakat. Sebagian masyarakat berpendapat bahwa kebijakan tersebut tidak berpihak kepada mereka. Pada sisi lain, bagi kelompok yang kontra, kebijakan India Rice yang anggap solusi oleh pemerintah hanya akan menambah kesengsaraan rakyat. Alasan inilah yang mendorong Haji Sarip melakukan gerakan protes terhadap kebijakan ini di Kabupaten Majalengka sebagai bentuk keprihatinan atas nasib rakyat secara umum.

Ia menilai kebijakan pemerintah sangat berbanding terbalik dengan keadaan sosial ekonomi masyarakat luas saat itu, mengingat kesejahteraan dan kebutuhan rakyat Indonesia masih belum tercukupi (ANRI, 1947. No. 57/R).

Alasan lain yang memicu adanya gerakan protes yang dipimpin oleh Haji Sarip ialah adanya ketidakpuasan terhadap aparatur-aparatur pemerintah, terutama pemerintah desa yang dulunya kerja kepada Belanda, sekarang diangkat oleh pemerintah sebagai kepanjangan tangan pemerintah Indonesia. Oleh karenanya, gerakan protes ini dapat dikatakan sebagai persaingan para elite desa, antara Haji Sarip dengan para pamong desa. Sedangkan kebijakan yang dikeluarkan oleh Pemerintah RI adalah sebagai pemicu saja dan dijadikan alat untuk melakukan mobilisasi dan provokasi terhadap masyarakat Jatiwangi dan sekitarnya untuk melawan para pamong desa.

\section{Riwayat Singkat Haji Sarip}

Berdasarkan hasil wawancara dengan Husein (wawancara, 22 April 2014), Haji Sarip sebenarnya bukan pituin Jatiwangi-Majalengka. Ia berasal dari Purwokerto dan pernah tercatat 
melakukan gerakan yang sama (gerakan protes di Majalengka) di Kabupaten Karawang. Kemudian, Haji Sarip melarikan diri ke wilayah JatiwangiMajalengka karena dikejar-kejar oleh aparat keamanan setempat dengan tuduhan telah menghasut masyarakat Karawang untuk melakukan perlawanan terhadap Pemerintah Indonesia. Masih menurut pemaparan Husein, Haji Sarip termasuk orang yang memiliki pengaruh besar dan dapat menarik hati orang banyak, karena kharismanya yang kuat, sehingga apa pun yang dikatakan oleh Haji Sarip, masyarakat segan untuk menolaknya.

Sebelum tiba di Majalengka, Haji Sarip juga terkenal dengan sebutan guru Tarekat Qodiiriyah-Naqsyanadiyah. Di samping itu, bulan September 1945, ia juga tercatat pernah mendirikan Badan Pembantoe Keselamatan Oemoem (B.P.K.O) di Jakarta, kemudian badan tersebut dilebur menjadi Persatuan Rakyat Marhua Indonesia (PERMAI). Anggotanya tersebar di beberapa wilayah di Kab. Majalengka di antaranya Kec. Dawuan, Leuwimunding, Jatitujuh, Jatiwangi, Ligung, dan Majalengka (ANRI, 1947. No. 58/R).

Di Kabupaten Majalengka, Haji Sarip mempunyai orang kepercayaannya yaitu Oesman. Sebagai orang kepercayaan Haji Sarip, Oesman diberikan fasilitias rumah. Sampai-sampai, ia dinikahkan kepada salah satu cucunya bermana Retno (anak dari Muhamad Siddik). Jabatan terakhir Oesman adalah ketua RW di salah satu desa di Kabupaten Majalengka (Desa Burujulwetan). (wawancara, Husein: 22 April 2014).

\section{Jalannya Peristiwa: Propaganda, A ksi Protes, dan A khir Peristiwa}

Untuk melancarkan aksinya dalam melakukan protes kepada pemerintah, bulan Januari 1947, Haji Sarip mendirikan sebuah organisasi Barisan Banteng yang di dalamnya terdapat sayap organisasi bernama pasukan Gaib. Kelompok ini mengajarkan tentang "kemanusiaan" yang berideologikan sama rata, sama rasa, sama warna, sama bangsa, dan benderanya hitam putih (ANRI, 1947. No. 58/R). Organisasi inilah yang dijadikan 'kendaraan' oleh Haji Sarip dalam memprotes pemerintah pada saat itu. Adapun anggota dari kelompok Gaib (ANRI, 1947. No. 58/R) di antaranya:

Abdullah (Mandirantjan Kab. Kuningan)

Taska (Indramajoe)

Kamar (Indramajoe)

Dajat (Indramajoe)

Kodja, Wardi, Karja (Majalengka)

Atma (Majalengka)

Asdijah (Majalengka)

Dardja (Majalengka)

Soekardi (Majalengka).

Dari kutipan di atas dapat disimpulkan bahwa kelompok Barisan Banteng tersebar bukan hanya di Kabupaten Majalengka melainkan ke seluruh Keresidenan Cirebon. Namun, karakteristik masyarakat Kab. Majalengka yang banyak sekali buruh dan petani sangat memungkinkan untuk menyebarkan paham yang Haji Sarip anut. Oleh sebab itu, Kab. Majalengka dipilih sebagai pusat dalam pembentukan kelompok Barisan Benteng. Sementara itu, tugas dari kelompok Barisan BentengPasukan Gaib adalah melakukan gerakan protes terhadap Pemerintah RI dan desa serta melakukan provokasi-agitasi terhadap masyarakat sekitar Kab. Majalengka untuk ikut dalam kelompoknya.

Selain itu pula, mereka gencar melakukan protes terhadap kebijakankebijakan Pemerintah RI dan menggantikannya dengan tatanan yang baru. Dengan berkumpul, membuat pamflet serta menyebarkannya.

"Pemerintah RI tidak adil memberi beras ke India, sedangkan rakyat masih kelaparan", itulah salah satu kalimat protes yang mereka buat dalam pamflet. 
Pola pergerakan itu pula yang disinyalir sebagai upaya Haji Sarip melakukan protes terhadap Pemerintah (wawancara, Husein: 22 April 2014).

Usaha lain dalam mempropaganda masyarakat, Djaidin (wawancara, 23 April 2014) menjelaskankan, Haji Sarip menyebarkan doktrin-doktrin kepada masyarakat dengan mengklaim dirinya sebagai ratu adil yang memberikan pemahaman-pemahaman bahwa dirinya sebagai juru selamat yang artinya siapa pun yang ikut dalam kelompoknya niscaya kebahagiaan akan datang dan segala bencana dihindarkan. Selain doktrin ratu adil yang diberikan kepada para anggotanya, ada doktrin lainnya yang Haji Sarip berikan kepada para anggotanya, doktrin itu adalah tentang sama rata, sama rasa, sama warna, sama bangsa. Dari doktrin sama rata sama rasa ini Haji Sarip seenaknya menyuruh anggotanya untuk membawa segala macam bahan-bahan makanan, karena yang diajarkan oleh Haji Sarip keanggotaan tentang kemanusiaan bahwa semua manusia itu sama tidak ada yang miskin dan yang kaya, tanpa adanya stratifikasi sosial, sehingga yang punya hewan ternak dan sawah berlebihan harus dibagikan kepada yang kekurangan dan membutuhkan.

Pemaparan Djaidin di atas diperkuat oleh Kusnan (wawancara, 22 April 2014), ia menyebutkan bahwa doktrin yang disebarkan kepada masyarakat oleh Haji Sarip adalah sama rata, sama rasa, sama warna, sama bangsa, dan benderanya putih-hitam. Hasil wawancara ini semakin diperkuat dengan dokumen (ANRI, 1947 No. 58/R):

"Sama warna sama bangsa artinja, bahwa orang hidup di dunia ini semua sama sadja asal dari Adam. Djadi, Belanda, Arab, Tionghoa dan lain-lain, berhak hidup djuga di dunia ini. Kita sebagai hamba Allah haruslah memegang peri kemanusian, tidak boleh saling membunuh meskipun orang itu Belanda. Oleh karena itu kita tidak perlu memanggul senapan, tidak menjadi tentara untuk membunuh bangsa2 lain”.

Berdasarkan uraian di atas dapat disimpulkan pula bahwa pemikiran yang dianut oleh Haji Sarip mengarah pada Sosialisme-Komunis, tidak jauh berbeda dengan Haji Misbach di era 1930-an. Haji Sarip menginginkan adanya sebuah perubahan tatanan pemerintahan baik secara sosial atau pun politik. Secara sosial, Haji Sarip menginginkan tidak adanya kelas di kalangan masyarakat, karena adanya sistem kelas mengakibatkan perbedaan dan dalam perbedaan itu selalu adanya konflik. Pada aspek politik, Haji Sarip menginginkan adanya perubahan tatanan pemerintah baik Pemerintah RI maupun desa. Tetapi sebenarnya gerakan protes Haji Sarip ini lebih cocok sebagai gerakan protes terhadap Pemerintah desa, karena gerakan protes yang dilakukan oleh Haji Sarip dan para anggotanya sering membuat resah pemerintah desa, sebagai contoh Haji Sarip dan para anggotanya sering menolak semua kerja yang diadakan oleh desa, mengejek para pamong desa dan akan mendaulat kepala desa (ANRI, 1947. No. 58/R). Boleh dikatakan bahwa gerakan protes Haji Sarip dalam upaya memprotes kebijakan-kebijakan Pemerintah RI hanya sebatas pemicu untuk menarik massa, sebenarnya tujuan yang paling utama dari Haji Sarip adalah melakukan gerakan protes terhadap pemerintah desa. Namun, kemungkinan besar gerakan protes Haji Sarip ini dalam perkembangannya dapat menjadi gerakan protes yang besar dan meresahkan masyarakat.

Pada awal pembentukan kelompok Gaib bulan Januari 1947 di Desa Burujul Wetan Kec. Jatiwangi Kab. Majalengka (wawancara, Husein: 22 April 2014), kelompok Gaib terus mengalami perkembangan yang cukup signifikan dari awalnya hanya satu kecamatan saja menjadi enam kecamatan yaitu: Kec. Jatiwangi, Kec. Ligung, Kec. Dawuan, Kec. Jatitujuh, Kec. Lewimunding dan Kec. Majalengka (ANRI, 1947. No. 
58/R). Menyebarnya gerakan protes Haji Sarip di beberapa wilayah di Kab. Majalengka bukan tanpa alasan, Haji Sarip yang dalam melakukan provokasinya memakai lambang-lambang agama Islam sangatlah efektif dalam menyentuh hati masyarakat Kab. Majalengka, karena masyarakat Kab. Majalengka tergolong religius pada saat itu, hal itu dapat dibuktikan dengan banyaknya ulama dan ustadz di Kab. Majalengka.

Proses penyebaran gerakan protes Haji Sarip dimulai dari Kec. Jatiwangi yang dipimpin oleh Haji Sarip sendiri. Selanjutnya menyebar ke Kec. Jatitujuh yang dipimpin oleh Asdijah; Atma dari Kec. Dawuan; Wardi dan Kardja dari Kec. Majalengka; Dardja dari Kec. Leuwimunding dan Soekardi dari Kec. Ligung (Sumber: ANRI, 1947. No. 58/R).

Sejumlah daerah yang dijadikan poros gerakan protes oleh Haji Sarip, disinyalir sebagai daerah yang mobilitas sosialnya tinggi dibandingkan yang lain. Itu pula sebagai landasan strategis dan efektif untuk menggalang kekuatan massa. (wawancara, Djaidin: 23 April 2014).

Sebenarnya, Kec. Jatiwangi yang merupakan sekretariat dari kelompok Gaib merupakan penghasil tebu terbesar di Kab. Majalengka. Di daerah yang terkenal dengan pabrik tebu itu Kelompok Gaib berjumlah 20 orang. Sementara itu, di Kec. Dawuan banyak petani yang dari pabrik gula yang secara aktifitas sosial dapat digerakan sebagai basis massa.

Pada umumnya, buruh pabrik gula yang bekerja di Kec. Dawuan merupakan penduduk asli Kec. Dawuan terutama masyarakat Desa Kasokandel, karena letak pabrik gula tersebut berada di Desa Kasokandel (Iyang, 22 April 2014).

Dari Kec. Dawuan penyebaran gerakan protes Haji Sarip berlanjut ke Kec. Jatitujuh yang secara geografis terletak di sebelah utara Kec. Jatiwangi. Di Kec. Jatitujuh juga mayoritas penduduknya bermata pencaharian sebagai petani. Alasan itulah yang menjadikan daerah Jatitujuh sebagai basis penyebaran dari Kelompok Haji Sarip. Maka, Kec. Jatitujuh merupakan salah satu daerah yang memiliki banyak pengikut dari gerakan protes Haji Sarip, anggotanya berjumlah kurang lebih 50 orang, jumlah ini lebih besar dari jumlah pengikut di Kec. Jatiwangi yang hanya berjumlah kurang lebih 20 orang (Husein, 22 April 2014).

Kurangnya jumlah pengikut di Kec. Jatiwangi dibandingkan dengan Kec. Jatitujuh disebabkan oleh beberapa faktor. Pertama, gerakan protes Haji Sarip meskipun terletak di daerah Kec. Jatiwangi bukan berarti mendapatkan tempat di hati masyarakat Kec. Jatiwangi, karena sebelum Haji Sarip tiba dan mendirikan organisasi di Kec. Jatiwangi, sudah banyak berdiri organisasi-organisasi yang jelas-jelas pro terhadap Pemerintah RI sebelumnya. Kedua, walaupun Haji Sarip menggunakan titel Haji di Kec. Jatiwangi tidak semata-mata masyarakat mempercayainya, karena di Kec. Jatiwangi pada tahun 1947 sudah banyak ulama. Sedangkan di Kec. Jatitujuh keadaan masyarakatnya masih dapat dipropaganda dan tidak begitu banyak organisasi yang berdiri di sana, sehingga hal tersebut memudahkan gerakan protes Haji Sarip dapat diterima oleh masyarakat Jatitujuh. Faktor-faktor tersebut yang menyebabkan gerakan protes Haji Sarip banyak pengikutnya di Kec. Jatitujuh (Djaidin, 23 April 2014).

Gerakan protes Haji Sarip selanjutnya menyebar ke daerah Kec. Ligung yang secara geografis terletak di sebelah utara dari Kec. Jatiwangi dan Jatitujuh. Di Kec. Ligung ini terdapat pabrik dan kebun tebu, sehingga daerah ini termasuk daerah target dari gerakan protes Haji Sarip guna memprovokasi para petani dan buruh untuk melakukan protes terhadap Pemerintah RI dan desa. Kekuatan yang paling besar di Kec. Ligung dari kelompok Haji Sarip ini yaitu di Desa Cibogor yang dipimpin oleh Soekardi, jumlah dari anggota Haji Sarip 
di Kec. Ligung ada 15 orang dari gabungan antara petani dan buruh (ANRI, 1947. No. 58/R). Gerakan protes Haji Sarip tidak sampai di situ saja, artinya terus mengalami perkembangan. Pada proses penyebarannya gerakan ini berlanjut ke Kec. Leuwimunding. Secara geografis Kec. Leuwimunding terletak di sebelah timur Kec. Jatiwangi dan sebelah selatan Kec. Ligung, mata pencaharian masyarakat di Kec. Leuwimunding mayoritas bekerja sebagai petani dan hal itu yang membuat Haji Sarip dan para anggotanya melanjutkan propaganda ke daerah tersebut, adapun jumlah anggota kelompok Gaib di Kec. Leuwimunding adalah 30 orang, jumlah ini merupakan jumlah terbanyak kedua setelah Kec. Jatitujuh (Iyang, 22 April 2014).

Terakhir penyebaran gerakan protes Haji Sarip di Kec. Majalengka. Secara geografis Kec. Majalengka terletak di sebelah selatan Kec. Jatiwangi dan Kec. Dawuan. Mayoritas penduduk Kec. Majalengka bermata pencaharian sebagai sebagai buruh pabrik, karena pada tahun 1947 di Kec. Majalengka terdapat bangunan/gudang penyimpanan gula. Jadi, gula-gula yang dihasilkan dari berbagai kecamatan di seluruh Kab. Majalengka dikumpulkan semuanya di gudang yang terletak di Kec. Majalengka. Adanya gudang tersebut setidaknya membutuhkan pekerja yang banyak untuk bongkar muat barang-barang. Hal itu dimanfaatkan oleh Haji Sarip untuk melakukan provokasinya dan mengumpulkan massa yang lebih besar lagi, akan tetapi jumlah anggota di Kec. Majalengka yang dapat direkrut oleh Haji Sarip hanya 10 orang. Hal itu disebabkan karena orang-orang yang bekerja di sana adalah para pekerja pabrik yang membawa barang dari Kec. Jatitujuh, sehingga hal itu menyebabkan perekrutan anggota di Kec. Majalengka sedikit (Husein, 22 April 2014).

Gerakan protes Haji Sarip dan para anggotanya dalam kurun waktu tiga bulan dimulai pada bulan Mei sampai dengan
Juli 1947 (ANRI, 1947. No. 57/R), berkembang ke beberapa wilayah di Kab. Majalengka seperti yang sudah dijelaskan di atas.

Tetapi yang menarik dalam gerakan protes Haji Sarip ini, yaitu dalam penyebarannya diprioritaskan ke daerahdaerah yang berbasis buruh pabrik dan tani.

Tidak salah, jika dikaitkan dengan garis ideologi Haji Sarip yang dekat dengan sosial-komunis-yang menjadi buruh tani, pabrik sebagai basis penggalan massa untuk melakukan perlawanan.

Selain itu, gerakan protes Haji Sarip ditujukan kepada orang-orang yang mudah dikendalikan, dalam artian tidak berpendidikan, dan berwawasan rendah sehingga memudahkan untuk dilakukan indoktrinasi.

Dengan cepat, gerakan protes Haji Sarip berkembang cukup besar dalam kurun waktu tiga bulan, karena sesuai yang sudah dijelaskan di atas bahwa Haji Sarip mempunyai anggota yang tersebar di beberapa wilayah Kab. Majalengka yang awalnya berjumlah tujuh orang (ANRI, 1947. No. 58/R), terutama di Kec. Jatiwangi, Kec. Ligung, Kec. Dawuan, Kec. Leuwimunding, Kec. Jatitujuh dan Kec. Majalengka.

Anggota Haji Sarip yang berjumlah tujuh orang tersebut sering berkumpul di rumah Haji Sarip, dalam perkumpulannya Haji Sarip sering bertukar pikiran tentang permasalahan yang sedang dihadapi, strategi-strategi dalam merekrut anggota dan mendoktrin tentang tujuan dari gerakan protes di Kab. Majalengka.

Dari doktrin-doktrin yang Haji Sarip lancarkan terhadap anggota yang tujuh orang tersebut, selanjutnya menyebar ke beberapa orang lainnya, karena melalui tujuh orang tersebut Haji Sarip dapat menyebarkan doktin-doktin dan alasan-alasan dalam melakukan gerakan protes di Kab. Majalengka. Pada akhirnya jika diakumulasikan, gerakan protes Haji Sarip yang awalnya beranggotakan tujuh orang berkembang 
menjadi 135 orang (Kusnan, 22 April 2014).

Akhir dari gerakan protes Haji Sarip di Kabupaten Majalengka melemah setelah Haji Sarip ditangkap oleh Pemerintah RI, dan pada akhirnya melemah dengan sendirinya karena ketiadaan sosok pemimpin pengganti yang memiliki kharisma kuat untuk mengagitasi serta memobilisasi masyarakat. Haji Sarip ditangkap oleh Pemerintah Indonesia dengan tuduhan (sebagaimana yang tertera dalam Arsip Nasional Republik Indonesia No. 57/R tahun 1947... Provokasi Haji Sarip tanggal 6-5-1947 jam 11 siang) sebagai beriku:

1. Melemahkan perjoeangan.

2. Menghina Tentara.

3. Menghina Pemerintah.

Pertama, Haji Sarip dianggap sebagai orang yang melemahkan perjuangan pemerintah dalam upaya mempertahankan kemerdekaan dan kedaulatan RI dari tangan Sekutu/Belanda, karena pada tahun 1947 keadaan RI masih dalam gejolak revolusi.

Kedua, Haji Sarip dianggap sebagai orang yang menghina tentara, karena Haji Sarip menyebarkan isu terhadap masyarakat Kab. Majalengka bahwa yang jadi tentara itu adalah orang dari kampung, orang tidak punya (miskin), sehingga kerjanya pun tidak maksimal (mencla-mencle). Selain itu, setiap ada jatah beras buat masyarakat selalu diambil oleh para tentara, oleh sebab itu masyarakat sering kekurangan beras (ANRI, 1947. No. 58/R). Tetapi, apa yang diisukan oleh Haji Sarip itu tidak benar, karena pada tahun 1947 tentara belum dapat jatah beras dari Pemerintah RI (Husein, 22 April 2014). Jadi, sebenarnya isu yang dilontarkan Haji Sarip itu merupakan sebagian cara untuk menggiring pola pikir masyarakat agar ikut dalam kelompoknya dan melakukan protes.

Ketiga, menghina Pemerintah RI dengan dalih bahwa Pemerintah RI sudah tidak dapat mengurusi rakyatnya sendiri, dengan bukti bahwa Pemerintah RI telah menjual beras ke India dengan harga murah, sedangkan rakyat masih dalam serba kekurangan akan kebutuhan hidupnya. Apabila melihat dari kepentingan politik itu merupakan upaya dalam melaksanakan diplomasi, tujuannya agar India mengakui adanya perjuangan bangsa RI untuk mempertahankan kemerdekaan. Sebenarnya dari ketiga alasan itu sudah jelas bahwa Haji Sarip melontarkan isu-isu tersebut untuk mencari massa agar masyarakat percaya dan ikut serta dalam melakukan gerakan protes terhadap Pemerintah RI.

Dari keterangan di atas jelas bahwa Haji Sarip, terang-terangan melakukan gerakan protes terhadap Pemerintah, dengan dalih bahwa pemerintah sudah tidak dapat menguasai dan mengurus rakyatnya sendiri. Persoalannya begitu jelas, ketika kemiskinan yang terusmenerus dialami rakyat jelata karena beras mereka habis oleh para Tentara.

Dengan demikian, perlawanan Haji Sarip terhadap pemerintah mendapatkan perhatian yang serius sehingga ia ditangkap oleh Kepolisian Keresidenan Cirebon (ANRI, 1947. No. 58/R).

Terdapat alasan-alasan lain yang membuat gerakan protes Haji Sarip berakhir dalam waktu relatif singkat: pertama, gerakan protes yang Haji Sarip lakukan kurang familiar di kalangan masyarakat sekitar Kab. Majalengka secara umum. Apabila gerakan sudah tidak populer dan tidak memiliki daya jual, maka ia akan hancur dengan sendirinya karena tidak adanya regenarasi; kedua, gerakan Haji Sarip hanya menguntungkan dia pribadi bukan untuk kepentingan khalayak umum, seperti contoh dalam setiap perkumpulan, masyarakat yang ikut dalam kelompoknya diwajibkan membawa bahan-bahan pokok yang disuruh oleh Haji Sarip, tetapi bahan-bahan pokok yang dibawa oleh para anggotanya dipakai buat kepentingan dia sendiri; ketiga, propaganda terhadap 
masyarakat kurang maksimal dan munculnya kesadaran masyarakat, karena Haji Sarip di samping merupakan orang pendatang, sehingga sulit untuk memprovokasi masyarakat Kab. Majalengka secara luas dan ajarannya pun dianggap melenceng dari akidah Islam yang senyatanya (wawancara, Oi: 23 April 2014).

\section{PEN UTUP}

Gerakan protes Haji Sarip di Kabupaten Majalengka merupakan bagian dari perlawanan sosial yang dipicu sebagai bentuk kekecewaan terhadap pemerintah akibat adanya penerapan kebijakan India Rice dan persaingan para elit setempat untuk mengubah tatanan pemerintahan lama dengan sistem pemerintahan baru yang yang berlandaskan pada asas sosialismekomunisme. Atas dasar ideologi itu, maka Haji Sarip lebih memprioritaskan masyarakat petani dan buruh sebagai ladang atau basis massa untuk melakukan protesnya terhadap pemerintah.

Namun, gerakan protes Haji Sarip tidak meninggalkan bekas yang berarti bagi masyarakat Kab. Majalengka, karena setelah kemerdekaan, masyarakat Kab. Majalengka lebih terfokus terhadap usaha untuk mempertahankan kemerdekaan RI. Hal ini dimungkinkan karena jalannya peristiwa yang berlangsung relatif sebentar, ditambah kurangnya juga dukungan dari masyarakat setempat serta ketiadaan pemimpin yang mampu mengagitasi masyarakat lainnya pasca tertangkapnya Haji Sarip oleh pihak keamanan yang merupakan kepanjangan tangan dari pemerintah yang berkuasa (Indonesia).

\section{DAFTAR SUMBER}

\section{A rsip}

Arsip Nasional. (1947).

Provokasi Haji Sarip Desa Broejoelwetan, Salinan II. Nomor 57/R

Arsip Nasional. (1947).

Gerak-Gerik Haji Sarip Desa Broejoelwetan, Salinan II. Nomor 58/R.

\section{Buku}

Depdiknas. 2008.

Kamus Besar Bahasa Indonesia. Jakarta: Departemen Pendidikan Nasional.

Falah, M. 2008

Riwayat Perjuangan K.H. Abdul Halim. Jawa Barat: Masyarakat Sejarawan Indonesia Cabang Jawa Barat.

Frederick, W.H. 2005.

Pemahaman Sejarah Indonesia: Sebelum dan Sesudah Revolusi. Jakarta: Pustaka LP3S Indonesia.

Gottschalk, L. 2008. Mengerti Sejarah. Jakarta: UI Press.

Ismaun. 2005.

Pengantar Belajar Sejarah sebagai Ilmu dan Wahana Pendidikan Bandung: Historia Utama Pers.

Kartodirdjo, Sartono. 1984. Ratu Adil. Jakarta: Sinar Harapan.

1992.

Pendekatan Ilmu Sosial dalam Metodologi Sejarah. Jakarta: Gramedia Pustaka Utama.

Lucas, A. 2003.

One Soul One Struggle, Peristiwa Tiga Daerah Revolusi dalam Revolusi. Jakarta: Resist Book.

Ricklefs, M.C. 2008. Sejarah Indonesia Modern 1200-2008. Jakarta: Serambi. 
Sudiyo. 2002.

Pergerakan Nasional Mencapai dan Mempertahankan Kemerdekaan. Jakarta: Rineka Cipta

Widja, G. 1988.

Pengantar Ilmu Sejarah: Sejarah dalam Perspektif Pendidikan. Semarang: Satya Wacana.

\section{Jurnal, dan Skripsi}

Mulyana, A. 2000.

"Pergumulan Elite Sunda pada Masa Revolusi: Kasus Berdiri dan Bubarnya Negara Pasundan, 1947-1950”. Historia: Jurnal Pendidikan Sejarah, 1 (1), hlm. 49-57.

Zuhdi, S. 2013.

"Antara Sewaka dan Soeria Kartalegawa: Dinamika Politik Pemerintahan di Jawa Barat pada Masa Revolusi Indonesia". Historia: Jurnal Pendidikan Sejarah, IV (7), hlm. 7994.

Kurniadi, D. 2002.

Karisidenan Priangan pada Masa Revolusi: Tinjauan Bidang Politik dan Militer (dari Proklamasi sampai Hijrah). Skripsi Program Jurusan Sejarah, Fakultas Sastra. UI. Tidak Diterbikan

\section{Internet}

Anonim. "Bagian 4: Rezim Pendudukan", http://etan.org/etanpdf/2006/CAVR/bh/ 04-Rezim-Pendudukan.pdf, (diakses tanggal 8 Maret 2014).

\section{Sumber Lisan/Informan}

Djaidin (88 tahun). 2014.

Ex Veteran, Pamong Desa Burujul Wetan, Pelaku Sejarah sekaligus Saksi Sejarah. Wawancara, Burujul Wetan, 23 April 2014.

H. Husein (90 tahun). 2014.

Ex TNI sekaligus Pelaku Sejarah. Wawancara, Burujul Wetan, 22 April 2014.

H. Kusnan (84 tahun). 2014.

Saksi Sejarah sekaligus Pelaku Sejarah. Wawancara, Jatiwangi, 22 April 2014.

H. Oi (85 tahun). 2014.

Pelaku Sejarah. Wawancara, Burujul Wetan, 23 April 2014.

Iyang.(83 tahun). 2014.

Saksi Sejarah. Wawancara, Burujul Wetan, 22 April. 